\title{
Kewenangan Praperadilan Dalam Menentukan Tersangka Pelaku Tindak Pidana
}

\begin{abstract}
Suharjo*
Asbtrak

Berdasarkan kewenangan Pasal 77 KUHAP, pengawasan praperadilan terhadap upaya paksa masih terbatas. Praperadilan hanya memeriksa dan memutus tentang upaya paksa terbatas pada penangkapan dan penahanan. Permasalahan pokok dalam penelitian ini apakah lembaga praperadilan memiliki wewenang untuk menentukan seseorang menjadi tersangka? Tujuan penelitian untuk menganalisis lembaga praperadilan memiliki wewenang untuk menentukan seseorang menjadi tersangka. Kegunaan penelitian dapat menambah khasanah keilmuan dalam bidang ilmu hukum. Metode penelitian menggunakan medtode deskrptif normatif. Hasil penelitian bahwa Lembaga praperadilan dalam sistem peradilan pidana memiliki fungsi sebagai lembaga pengawas, dengan tujuan pengawasan yang dilakukan oleh lembaga praperadilan adalah untuk memberikan perlindungan terhadap hak-hak asasi manusia terutama tersangka dan terdakwa. Namun masih ada kelemahan dalam praktek yaitu masih terbatasnya kewenangan praperadilan terkait pengawasan terhadap upaya paksa yang hanya meliputi penangkapan dan penahanan. Kesimpulan Hakim praperadilan bersifat menunggu, sehingga tidak ada pemeriksaan jika tidak ada pihak yang mengajukan permohonan. Dalam praktek hakim hanya memeriksa mengenai syarat formil dari suatu upaya paksa tanpa memperhatikan syarat materiil. Selain itu perbedaan dasar pertimbangan hakim dalam menjatuhkan putusan dan juga dibatasinya waktu yang singkat dalam 18 pemeriksaan perkara sesuai dengan pasal 82 ayat (1) huruf c KUHAP sehingga perkara gugur dengan sendirinya. Tidak hanya itu, terkait juga dengan pasal 80 KUHAP yaitu mengenai interpretasi pihak ketiga yang berkepentingan dalam mengajukan permohonan praperadilan.
\end{abstract}

Kata Kunci : Kewenangan, Praperadilan, Pelaku, Tindak Pidana

\section{Pretrial Authority In Determining Actual Criminal Actors}

\begin{abstract}
Under the authority of Article 77 of the Criminal Procedure Code, pretrial oversight of forced efforts is still limited. Pretrial only examined and decided that forced efforts were limited to arrest and detention. The main problem in this study is whether the pretrial institution has the authority to determine someone to be a suspect? The research objective is to analyze pretrial institutions which have the authority to determine who is a suspect. The usefulness of research can add to the realm of science in the field of law. The research method uses normative descriptive methods. The results of the study that pretrial institutions in the criminal justice system have a function as a supervisory institution, with the aim of supervision conducted
\end{abstract}

*E-mail: suharjo89@gmail.com 
by pretrial institutions is to provide protection for human rights, especially suspects and defendants. However, there are still weaknesses in practice, namely the still limited pretrial authority regarding oversight of forced measures which only includes arrest and detention. Conclusions Pretrial judges are awaiting, so there is no examination if no party submits an application. In practice the judge only examines the formal requirements of a forced attempt without regard to the material requirements. In addition, the basic difference of the judge's consideration in issuing a decision and also limited the short time in 18 hearings in accordance with article 82 paragraph (1) letter $c$ of the Criminal Procedure Code so that the case falls automatically. Not only that, it is also related to article 80 of the Criminal Procedure Code which is about the interpretation of third parties who have an interest in submitting a pretrial petition.

Keywords: Authority, Pretrial, Perpetrators, Criminal Acts

\section{Pendahuluan}

Praperadilan merupakan lembaga baru dalam dunia peradilan di Indonesia. Praperadilan bukan merupakan lembaga penegakan hukum yang berdiri sendiri. Sejalan dengan berkembangnya pemikiran hukum maka lahirlah UndangUndang Nomor 8 Tahun 1981 tentang Hukum Acara Pidana sebagai pengganti Het Herzeine Inlandsch Reglement. Pada prinsipnya, KUHAP melahirkan lembaga praperadilan sebagai kelembagaan untuk mengadakan tindakan pengawasan terhadap aparat penegak hukum agar dalam melaksanakan kewenangannya tidak menyalahgunakan wewenang besar yang melekat padanya. Sebagai ilustrasi, kegiatan penyidik yang implementasinya dapat berupa penangkapan bahkan penahanan, sifatnya memaksa menyingkirkan asas yang diakui secara universal yaitu hak asasi manusia. (Ratna Nurul Alfiah, 1986: 35)

Dengan kalimat lain, praperadilan berfungsi sebagai sarana pengawasan terhadap tindakan penegak hukum dalam hal penuntutan dalam sistem peradilan pidana di Indonesia. Pengawasan tersebut bertujuan memberikan perlindungan terhadap hak asasi tersangka atau terdakwa. Sebenarnya secara otomatis pengawasan atau kontrol terhadap tiap aparat penegak hukum telah melekat pada lembaga aparat penegak hukum itu bernaung. Namun demikian, dirasakan dengan bentuk pengawasan lain seperti kelembagaan praperadilan, pengawasan terhadap implementasi kewenangan penegak hukum akan lebih efektif. 
Dengan demikian, dapatlah dikatakan bahwa negara memberikan kewenangan kepada aparat penegak hukum untuk menegakkan keadilan dengan melakukan upaya paksa yang mengesampingkan perlindungan terhadap hak asasi manusia. Namun disadari bahwa penegak hukum juga dapat melakukan kesalahan dan pelanggaran terhadap hak-hak asasi dari pelaku tindak pidana dalam upaya paksa yang dilakukan. Oleh karena itu, KUHAP selain memberikan kewenangan pada penegak hukum untuk melakukan upaya paksa, juga menjamin terlindungnya hak-hak pelaku tindak pidana.

Berdasarkan Pasal 1 angka 10 KUHAP, yang dimaksud praperadilan adalah wewenang pengadilan negeri untuk memeriksa dan memutus menurut cara yang diatur dalam Undang-Undang ini, tentang:

a. Sah atau tidaknya suatu penangkapan dan atau penahanan atas permintaan tersangka atau keluarganya atau pihak lain atas kuasa tersangka;

b. Sah atau tidaknya penghentian penyidikan atau penghentian penuntutan atas permintaan demi tegaknya hukum dan keadilan;

c. Permintaan ganti kerugian atau rehabilitasi oleh tersangka atau keluarganya atau pihak lain atas kuasanya yang perkaranya tidak diajukan ke pengadilan.

Selanjutnya dalam Pasal 77 KUHAP, diatur bahwa Pengadilan Negeri berwenang untuk memeriksa dan memutus, sesuai dengan ketentuan yang diatur dalam Undang-Undang ini tentang:

a. sah atau tidaknya penangkapan, penahanan, penghentian penyidikan atau penghentian penuntutan;

b. ganti kerugian dan atau rehabilitasi bagi seorang yang perkara pidananya dihentikan pada tingkat penyidikan atau penuntutan.

Lembaga praperadilan secara tidak langsung melakukan pengawasan atas kegiatan yang dilakukan penyidik dalam rangka penyidikan maupun penuntutan, mengingat tindakan penyidik pada dasarnya melekat pada institusi yang bersangkutan. Sistem pengawasan antar institusi ini merupakan salah satu hal yang krusial dalam proses penegakan hukum pada era supremasi hukum, agar kepastian hukum benar-benar dapat diberikan bagi para pencari keadilan. 
Dalam sistem peradilan pidana terpadu yang dianut oleh hukum acara pidana mengandung arti hubungan antara kepolisian, kejaksaan, kehakiman, dan lembaga pemasyarakaatan harus merupakan hubungan yang sinkron dan bersinergi. Sebagaimana diketahui masing-masing lembaga seperti kepolisian, kejaksaan, mahkamah agung, dan lembaga pemasyarakatan memiliki undangundangnya sendiri, sehingga bila masing-masing lembaga tersebut berjalan sendiri-sendiri untuk mengatasi kejahatan, apa yang menjadi tujuan bisa saja tidak tercapai. Oleh karena itu lembaga praperadilan sebagai lembaga pengawas oleh hakim terhadap tindakan-tindakan yang dilakukan oleh kepolisian maupuan kejaksaan akan mewujudknya tercapainya apa yang dikehendaki oleh sistem peradilan pidana terpadu tersebut.

Sistem peradilan pidana terpadu bukan diartikan bahwa masing-masing subsistem yang ada dalam sistem tersebut memiliki kewenangan tersendiri yang terlepas dari fungsi subsistem-subsistem lain. Agar sistem dapat bekerja secara optimal, harus ada keterpaduan dalam pemisahan (unity in diversity) sehingga walaupun masing-masing subsistem memiliki kewenangan tersendiri, tetapi harus memberikan masukan bagi subsistem yang lain. Dengan demikian, output dari suatu subsistem, merupakan input bagi subsistem yang lain, sehingga kesinambungan dari suatu sistem bukan seperti kartu domino namun merupakan kesatuan seperti mata rantai, bahwa keterpaduan dalam sistem harus tercipta dari hulu sampai ke hilir.(Luhut M.Pangaribuan: 2009: 44)

Dalam perkembangannya, praperadilan dianggap tidak berjalan sebagaimana mestinya karena masih memiliki banyak kelemahan dan kekurangan serta dalam prakteknya tidak sesuai dengan ketentuan yang diatur dalam KUHAP. Dengan hadirnya RUU KUHAP, terdapat satu ide bahwa terdapat peralihan dari lembaga praperadilan menjadi Hakim Pemeriksa Pendahuluan untuk melengkapi kekurangan dan kelemahan dari lembaga praperadilan tersebut.

Lembaga praperadilan memiliki batasan kewenangannya dalam melakukan pengawasan terhadap upaya paksa penegak hukum. Selain yang sudah diatur dalam KUHAP, Mahkamah Konstitusi juga telah mengeluarkan putusan yang 
memperluas kewenangan lembaga praperadilan yang tidak hanya mengacu pada ketentuan Pasal 77 KUHAP. Penelitian yang akan dilakukan oleh penulis bukan permasalahan normatif dari KUHAP secara keseluruhan, namun hanya terfokus pada permasalahan perluasan kewenangan praperadilan sesuai KUHAP dan regulasi lainnya, sebagai salah satu bentuk pengawasan dalam integrated criminal justice system.

Berdasarkan latar belakang tersebut, maka permasalahan penelitian :

a. Bagaimana perkembangan hukum lembaga praperadilan?

b. Apakah lembaga praperadilan memiliki wewenang untuk menentukan seseorang menjadi tersangka?

\section{Pembahasan}

\section{A. Pembatasan Kewenangan Lembaga Praperadilan}

Tujuan dari praperadilan dapat diketahui dari penjelasan Pasal 80 KUHAP yang menegaskan bahwa tujuan dari pada praperadilan adalah untuk menegakkan hukum, keadilan, kebenaran melalui sarana pengawasan horizontal. Esensi dari praperadilan, untuk mengawasi tindakan upaya paksa yang dilakukan oleh penyidik atau penuntut umum terhadap tersangka, supaya tindakan itu benar-benar dilaksanakan sesuai dengan ketentuan Undang-undang, benar-benar proporsional dengan ketentuan hukum, bukan merupakan tindakan yang bertentangan dengan hukum. Menempatkan tersangka bukan sebagai objek yang diperiksa, penerapan asas aqusatoir dalam hukum acara pidana, menjamin perlindungan hukum dan kepentingan asasi. Hukum memberi sarana dan ruang untuk menuntut hak-hak yang dikebiri melalui praperadilan.

Berdasarkan kewenangan Pasal 77 KUHAP, pengawasan praperadilan terhadap upaya paksa masih terbatas. Praperadilan hanya memeriksa dan memutus tentang upaya paksa terbatas pada penangkapan dan penahanan. Untuk tindakan penggeledahan dan penyitaan ataupun pemeriksaan surat tidak dijelaskan oleh KUHAP, sehingga menimbulkan ketidakjelasan siapa yang berwenang memeriksa apabila terjadi pelanggaran di dalam upaya dimaksud. Demikian halnya dengan ketentuan Pasal 80 KUHAP mengenai pengajuan 
pemeriksaan tentang sah atau tidaknya penghentian penyidikan maupun penuntutan yang diajukan oleh pihak ketiga yang berkepentingan, KUHAP tidak memberikan interpretasi yang jelas mengenai siapa yang dimaksud dengan pihak ketiga yang berkepentingan dalam pasal tersebut. Ketidakjelasan tersebut mempengaruhi perbedaan penafsiran hakim terhadap interpretasi mengenai siapa pihak ketiga yang berkepentingan.

Hakim praperadilan bersifat pasif, artinya "tidak ada sidang tanpa adanya tuntutan dari pihak-pihak yang berhak memohon pemeriksaan praperadilan". Dengan demikian, meskipun terdapat suatu penyimpangan secara nyata dan jelas dalam upaya paksa, tetapi pihak-pihak yang dirugikan tidak mengajukan permohonan maka hakim praperadilan tidak dapat menguji dan memutus kebenaran dari upaya paksa tersebut.

Dibatasinya waktu dalam proses beracara dalam beberapa perkara ternyata merupakan masalah dalam praperadilan. Berdasarkan ketentuan Pasal 82 ayat (1) huruf c KUHAP ditentukan bahwa pemeriksaan dilakukan secara cepat dan selambat-lamabtnya dalam 7 (tujuh) hari hakim sudah harus menjatuhkan putusannya. Jika proses beracara perkara praperadilan tidak selesai dalam 7(tujuh) hari maka perkara praperadilan dianggap gugur. Dibatasinya waktu tersebut mengacu pada salah satu asas dalam sistem peradilan pidana yaitu asas peradilan cepat, sederhana, dan biaya ringan.

\section{B. Penetapan Tersangka oleh Lembaga Praperadilan}

Dalam proses perkara pidana aparat yang paling depan yaitu aparat kepolisian, aparat kepolisian inilah yang pertama kali memfliter suatu perkara sebelum di ajukan kekejaksaan dan pengadilan. Fungsi praperadilan adalah sebagai kontrol vertikal external dan internal serta kontrol horizontal antar aparat penyidik dan penuntut umum untuk dapat saling mengajukan permohonan praperadilan.

Salah satu putusan praperadilan Nomor: 24/Pid/Pra/2018/PN.Jkt.Sel. Putusan praperadilan ini dengan permohonan yang diajukan oleh Masyarakat Anti Korupsi (MAKI) terkait dengan perkara korupsi Bank Century. Dalam 
putusannya, hakim tunggal Effendi Mukhtar, menjatuhkan amar yaitu memerintahkan Komisi Pemberantasan Korupsi (KPK) untuk melakukan proses hukum selanjutnya sesuai dengan ketentuan hukum dan peraturan perundangundangan yang berlaku terkait dengan dugaan tindak pidana korupsi Bank Century dalam bentuk melakukan Penyidikan dan menetapkan tersangka terhadap Boediono, Muliaman D Hadad, Raden Pardede, dan kawan-kawan (sebagaimana yang tertuang dalam dakwaan atas nama Terdakwa Budi Mulya) atau melimpahkannya kepada Kepolisian dan/ atau Kejaksaan untuk dilanjutkan dengan melakukan Penyelidikan, Penyidikan, dan Penuntutan dalam proses persidangan di Pengadilan Tipikor Jakarta Pusat.

Petikan putusan tersebut di atas memberikan dua kemungkinan bagi KPK dalam melaksanakan putusan ini, yaitu:

1. Menindaklanjuti penyidikan dengan menetapkan Boediono, Muliaman D Hadad, Raden Pardede, dkk sebagai tersangka; atau

2. Melimpahkan kasus tersebut ke Kepolisian dan Kejaksaan untuk dapat ditindaklanjuti.

Jika melihat putusan tersebut maka yang menjadi pertanyaan adalah apakah lembaga praperadilan memiliki kewenangan dalam memerintahkan penegak hukum untuk menetapkan seseorang menjadi tersangka?

Terkait dengan kasus dugaan korupsi Bank Century, KPK dalam berbagai kesempatan menerangkan bahwa KPK terus melanjutkan proses hukum dugaan korupsi Bank Century namun memang setelah putusan Budi Mulya berkekuatan hukum tetap (inkracht) nama-nama yang berada dalam dakwaan Budi Mulya yang dikatakan secara bersama-sama melakukan tindak pidana korupsi yakni Boediono, Muliaman D Hadad, Raden Pardede, dkk tidak kunjung ditetapkan jadi tersangka. Konteks inilah yang menimbulkan pertanyaan apakah prosesnya dihentikan atau masih berlanjut? Jika prosesnya dihentikan maka menjadi kewenangan lembaga praperadilan untuk memutuskan bahwa apakah penghentian penyidikan itu sah atau tidak. 
Hakim Effendi Mukhtar dalam putusannya memerintahkan KPK untuk melanjutkan proses hukum terhadap Boediono, Muliaman D Hadad, Raden Pardede, dkk ini sebenarnya menandakan bahwa anggapan hakim adalah dengan belum atau tidak dilanjutkannya proses penyidikan terhadap Boediono, Muliaman D Hadad, Raden Pardede, dkk merupakan bentuk penghentian penyidikan. Penafsiran seperti ini secara yuridis adalah sah, karena secara akademis penafsiran hukum merupakan suatu hal yang lazim dilakukan. Tetapi terkait dengan perintah agar KPK menetapkan Boediono, Muliaman D Hadad, Raden Pardede, dkk sebagai tersangka, dalam hal ini sebenarnya "bukan merupakan kewenangan dari lembaga praperadilan".

Jika kita melihat dalam Pasal 1 angka 2 jo. Pasal 7 KUHAP sebenarnya yang memiliki kewenangan untuk melakukan penetapan tersangka penegak hukum (dalam hal ini penyidik), begitu pun juga terkait dengan perintah untuk membawa perkara tersebut ke pengadilan sebenarnya hal ini bukan merupakan kewenangan lembaga praperadilan karena kewenangan untuk melimpahkan kasus ke pengadilan adalah kewenangan penuntut umum sesuai dengan azas dominus litis.

Perintah dalam putusan praperadilan untuk menetapkan Boediono, Muliaman D Hadad, Raden Pardede, dkk sebagai tersangka sebenarnya bukan ranah dalam kewenangan lembaga praperadilan. Kewenangan lembaga praperadilannya sangat terbatas, yang dimaksudkan agar penegakan hukum dapat sesuai dengan prosedur hukum.

Secara yuridis, penanganan kasus Bank Century memang perlu dilakukan percepatan dengan pertimbangan kasus ini sudah berjalan lama, bahkan untuk menangani permasalahan Bank Century ini juga telah dilakukan berbagai cara termasuk membentuk Panitia Hak Angket Century sampai dengan Tim Pengawas Angket Century untuk melakukan pengawasan atas rekomendasi hak angket Century.

Perlu diketahui bahwa dalam Putusan yang telah berkekuatan hukum tetap (inkracht), Boediono, Muliaman D Hadad, Raden Pardede, dkk dikatakan telah melakukan atau turut serta melakukan tindak pidana korupsi dengan terdakwa 
Budi Mulya. Pada saat KPK membacakan dakwaan pada tahun 2014 terhadap Budi Mulya, Jaksa KPK juga mengatakan adanya keterlibatan Boediono, Muliaman D Hadad, Raden Pardede, dkk secara bersama-sama.

Terkait dengan pembacaan dakwaan ini, apakah Jaksa KPK telah mengatakan bahwa Boediono, Muliaman D Hadad, Raden Pardede, dkk melakukan atau turut serta melakukan (vide Pasal 55 KUHP), seharusnya sudah ada bukti permulaan yang dapat menjerat semuanya, karena jika belum ada bukti permulaan maka seharusnya KPK tidak mencantumkan Pasal 55 KUHP terhadap dakwaan dan tuntutan Budi Mulya.

Konsekuensi logis dari penerapan Pasal 55 KUHP terhadap Boediono, Muliaman D Hadad, Raden Pardede, dkk dalam perkara Budi Mulya maka mereka yang disebutkan dalam dakwaan tersebut harus dituntut juga dan diajukan sebagai tersangka dan harus pula dijatuhkan pidana.

Kewenangan untuk melakukan penetapan tersangka sesuai peraturan perundang-undangan ada di tangan penyidik (dalam hal ini KPK) terkait dengan putusan praperadilan yang memerintahkan agar Boediono, Muliaman D Hadad, Raden Pardede, dkk ditetapkan sebagai tersangka sebenarnya, karena pada dasarnya lembaga praperadilan tidak memiliki kewenangan dalam memerintahkan agar seseorang ditetapkan menjadi tersangka.

Namun pada sisi lain, terdapat kewajiban bagi KPK untuk mematuhi Putusan Pengadilan yakni putusan praperadilan karena dengan alasan apapun putusan pengadilan harus dipatuhi terlepas putusan ini baik atau kurang baik. Hal yang perlu diingat adalah apabila KPK akan melaksanakan putusan praperadilan dimaksud perlu diperhatikan terkait alat bukti karena jika alat bukti belum memenuhi syarat maka tersangka dapat mengajukan pembatalan status tersangkanya di praperadilan.

\section{Analisis Yuridis Kedudukan Hakim Pemeriksa Pendahuluan dalam Sistem Peradilan Pidana}

Praperadilan berfungsi sebagai sarana pengawasan terhadap tindakan Kepolisian dalam hal penyidikan maupun Kejaksaan dalam hal penuntutan di 
dalam Sistem Peradilan Pidana di Indonesia. Pengawasan tersebut bertujuan memberikan perlindungan terhadap hak asasi tersangka atau terdakwa. Dalam praktiknya, lembaga praperadilan dianggap tidak sesuai dengan KUHAP dan juga memiliki banyak kelemahan serta kekurangan. Dengan hadirnya RUU KUHAP, terdapat satu ide bahwa terdapat peralihan dari lembaga praperadilan menjadi Hakim Pemeriksa Pendahuluan yang memiliki wewenang lebih luas dari lembaga praperadilan.

Hadirnya RUU KUHAP merupakan pembaharuan terhadap KUHAP. Meskipun KUHAP merupakan pembaharuan total dari kitab HIR namun ternyata dalam praktek ditemukan banyak kekurangan dan kelemahan, sehingga muncul pemikiran baru dari para ahli hukum untuk memperbaiki kekurangan dan kelemahan tersebut.

Melihat kelebihan dan kekurangan lembaga praperadilan maupun Hakim Pemeriksa Pendahuluan dalam RUU KUHAP, maka pilihan pengawasan dalam tahap pemeriksaan pendahuluan atau tahap pra adjudikasi dalam sistem peradilan pidana lebih tepat jika dilakukan oleh lembaga praperadilan. Akan tetapi aturan-aturan dalam KUHAP mengenai wewenang dari lembaga tersebut perlu disempurnakan. Hal tersebut untuk menyesuaikan perkembangan hukum serta tuntutan keadilan dalam pembaharuan sistem.

Dalam RUU HAP terdapat lembaga pengganti praperadilan yang disebut dengan Hakim Pemeriksa Pendahuluan. Istilah Hakim Pemeriksa Pendahuluan dalam RUU HAP sebelumnya disebut dengan hakim komisaris. Model Hakim Pemeriksa Pendahuluan mengambil model pengawasan yang menjadi tradisi sistem peradilan Eropa Kontinental.

Istilah Hakim Komisaris sebenarnya bukan barang baru di Indonesia, sebab pada saat diberlakukannya Reglement op de Strafvoerdering, hal itu sudah diatur dalam title kedua tentang Van de regter-commissaris berfungsi pada tahap pemeriksaan pendahuluan sebagai pengawas (examinating judge) untuk mengawasi apakah tindakan upaya paksa (dwang middelen) serta dapat melakukan tindakan eksekutif (investigating judge) (Oemar Seno Adji \& 
Indriyanto, 2007: 186). Akan tetapi, setelah diberlakukan HIRdengan Staatsblad No. 44 Tahun 1941, istilah regter-commissaris tidak digunakan lagi.

Selanjutnya istilah Hakim Komisaris mulai muncul kembali dalam konsep RUU KUHAP yang diajukan ke DPR pada tahun 1974. Dalam konsep ini, Hakim Komisaris memiliki wewenang pada tahap pemeriksaan pendahuluan untuk melakukan pengawasan pelaksanaan upaya paksa (dwang middelen), bertindak secara eksekutif untuk ikut serta memimpin pelaksanaaan upaya paksa, menentukan penyidik mana yang melakukan penyidikan apabila terjadi sengketa antara polisi dan jaksa, serta mengambil keputusan atas keberatankeberatan yang diajukan oleh pihak-pihak yang dikenakan tindakan (Oemar Seno Adji, 1984:88).

Latar belakang diintrodusirnya Hakim Komisaris adalah untuk lebih melindungi jaminan hak asasi manusia dalam proses pidanan dan menghindari terjadinya kemacetan oleh timbulnya selisih antara petugas penyidik dari instansi yang berbeda. Penangkapan dan penahanan yang tidak sah merupakan pelanggaran serius terhadap hak asasi kemerdekaan dan kebebasan orang. Penyitaan yang tidak sah merupakan pelanggaran serius terhadap hak milik orang, dan penggeledahan yang tidak sah merupakan pelanggaran terhadap ketentraman rumah tempat kediaman orang. Jika diteliti lebih jauh, dasar pemikiran adanya Hakim Komisaris dalam sistem Eropa Kontinental, antara lain Belanda, sebenarnya tidak bisa dilepaskan daripada fungsi Hukum Acara Pidana yang bertujuan mencari dan menemukan kebenaran sejati serta menjalankan atau melaksanakan hukum pidana materiil. Hukum pidana materiil memiliki asas fundamental bahwa tidak ada suatu tindak pidana tanpa ada undang-undang yang mengatur sebelumnya (nullum delictum nulla poena praviae siena lege poenali).

Pengawasan Hakim Komisaris pada dasarnya merupakan hak kontrol dari pihak yudikatif (control van rechterlijkemacht) terhadap eksekutif. Karena itulah Hakim diberi wewenang yang demikian luas mencampuri bidang tugas Penyidik maupun Penuntut Umum dalam hal pemeriksaan pendahuluan. Sekalipun demikian di Negeri Belanda sendiri sampai sekarang, masih menjadi 
persoalan sampai sejauh mana batasan wewenang Hakim Komisaris dalam mengawasi pemeriksaan pendahuluan, karena dianggap mencampuri bidang eksekutif yaitu bidang penyidikan yang merupakan wewenang Penyidik dan atau Kejaksaan selaku Penuntut Umum.

Dalam naskah terbaru RUU HAP, model yang ditawarkan (selain perluasan kewenangan lembaga praperadilan), adalah Hakim Pemeriksa Pendahuluan (sebagai pengganti Hakim Komisaris). Pertimbangan perubahan substansi Hakim Komisaris menjadi Hakim Pemeriksa Pendahuluan, antara lain model Hakim Komisaris yang pada dasarnya mengambil model pengawasan yang menjadi tradisi sistem peradilan Eropa Kontinental seperti halnya Belanda, mengandung beberapa kelemahan mendasar dibandingkan dengan lembaga praperadilan. Kelemahan-kelemahan tersebut antara lain:

1. Dilihat dari konsep dasarnya, kedua sistem tersebut memiliki konsep yang berbeda, sekalipun tujuannya sama yaitu sama-sama melindungi hak asasi manusia terhadap tindakan upaya paksa yang dilakukan oleh Penyidik dan Penuntut Umum. Dalam kekuasaan negara, yakni hak kontrol dari kekuasaan kehakiman (yudikatif) terhadap jalannya pemeriksaan pendahuluan yang dilakukan oleh pihak eksekutif berdasarkan wewenangnya. Sedangkan lembaga Praperadilan bersumber pada hak habeas corpus yang pada dasarnya memberikan hak kepada seseorang yang dilanggar hak asasinya untuk melakukan perlawanan (redress) terhadap tindakan upaya paksa yang dilakukan oleh Penyidik atau Jaksa dengan menuntut yang bersangkutan di muka Pengadilan agar mempertanggungjawabkan perbuatannya dengan membuktikan bahwa upaya paksa yang dilakukan tersebut tidak melanggar hukum (ilegal) melainkan sah adanya. Perbedaan hakiki tersebut membawa konsekuensi bahwa dalam konsep Hakim Komisaris, kemerdekaan seseorang amat digantungkan pada "belas kasihan" negara, khususnya Kekuasaan Kehakiman untuk melaksanakan fungsi pengawasannya terhadap pihak eksekutif (Penyidik dan Penuntut Umum) dalam menjalankan pemeriksaan pendahuluan. Sedangkan dalam konsep Praperadilan, kemerdekaan orang 
itu memberikan hak fundamental padanya untuk melawan dan menuntut negara, dalam hal ini pihak eksekutif yaitu Penyidik dan Penuntut Umum.

2. Sistem pemeriksaan oleh Hakim Komisaris pada dasarnya bersifat tertutup (internal) dan dilaksanakan secara individual oleh hakim yang bersangkutan terhadap Penyidik, Penuntut Umum, saksi-saksi bahkan juga Terdakwa. Sekalipun pemeriksaan itu dilakukan secara objektif dan profesional, namun karena sifatnya yang tertutup, maka tidak ada transparansi dan akuntabilitas publik, sebagaimana halnya proses pemeriksaan sidang terbuka dalam forum Praperadilan. Dalam kondisi sekarang, syarat transparansi dan akuntabilitas publik ini amat diperlukan, terutama dalam menghadapi korupsi, kolusi dan nepotisme yang sudah melanda bidang peradilan.

3. Pengawasan oleh Hakim Komisaris dalam sistem peradilan Eropa Kontinental, antara lain Belanda, merupakan bagian integral dari keseluruhan sistem pengawasan hierarkis, yang dilakukan Hakim (justitie), terhadap Jaksa (Openbaar Ministrie) dan Kepolisian. Dalam sistem tersebut, Hakim mengawasi Jaksa, dan selanjutnya Jaksa mengawasi Polisi sebagai satu kesatuan sistem pengawasan integral yang harmonis dan serasi, maka apabila konsep ini mau diterapkan, syaratnya ketiga fungsionaris tersebut (Hakim, Jaksa dan Polisi), sekalipun masing-masing merupakan instansi yang berdiri sendiri, namun didalam bidang peradilan atau proses poemeriksaan perkara dari tingkat penyelidikan, penyidikan, penuntutan sampai dengan pemeriksaan di muka persidangan pengadilan secara fungsional adalah merupakan satu rangkaian hierarki kesatuan fungsi yang berbagi tugas dan wewenang namun saling melengkapi. Sistem ini dahulu pernah dimiliki oleh negara kita sebagai bekas jajahan Belanda sesuai asas konkordansi. Namun sejak Dekrit 5 Juli 1959 sistem tersebut sudah dirobah (retool), sesuai dengan tuntutan Demokrasi Terpimpin, dimana ketiga instansi tersebut masing-masing menjadi berdiri sendiri-sendiri dan terpisah secara tajam. Masing-masing instansi menolak campur tangan instansi lainnya, seperti Kejaksaan menolak campur tangan Hakim, dan Kepolisian juga menolak campur tangan Hakim, dan Kepolisian juga menolak campur 
tangan Kejaksaan. Dari uraian di atas dapat ditarik suatu kesimpulan bahwa konsep Hakim Komisaris tidak cocok dan ideal diterapkan di Indonesia pada saat ini.

4. Kelembagaan Hakim Komisaris menuntut kompetensi yang maksimal dari fungsi hakim sebagai Lembaga, karena setiap langkah Penyidik dan Penuntut Umum telah diuji oleh kelembagaan Hakim Komisaris. Persoalan yang mendasar adalah apakah dengan kewenangan yang maksimal tersebut dan sistem rekrut serta tidak ada chek and balance kelembagaan, hal ini akan berjalan dengan semestinya.

Pola rekruitmen Hakim, Jaksa dan Perwira Polri yang birokratis cenderung membuat sebaran sumber daya yang seimbang, sehingga dengan kewenangan berlebih dalam satu kelembagaan tanpa kompetensi, terlebih lagi dengan tidak adanya check and balance dimungkinkan ada ketimpangan dan timbul penyimpangan yang bersifat subordinasi, studi dan kasus-kasus yang berkembang menunjukkan hal tersebut. Pola Hakim Komisaris dengan pekerjaan dan kegiatannya tersebut tidak cocok dilakukan di Indonesia yang geografisnya luas serta masih banyak tempattempat yang belum terjangkau oleh transportasi secara cepat. Kelembagaan Hakim Komisaris berjalan optimal ketika lokasi atau tempat berdekatan, sehingga lokasi peradilan, Kejaksaan dan Kepolisian dapat ditempuh dengan mudah.

5. Kelembagaan Hakim Komisaris yang diintrodusir membutuhkan dua Hakim Komisaris setiap Pengadilan Negeri dan ini berarti dibutuhkan lebih kurang 500 x 2 Hakim Komisaris. Sumber daya dibutuhkan sebanyak 1000 orang setingkat Ketua Pengadilan. Dibutuhkan sarana dan prasarana unuk menunjang kurang lebih 500 Pengadilan Negeri tadi yang pelaksanaannya menggunakan anggaran yang sangat luar biasa bukan saja miliyaran tetapi triliyun. Bandingkan amanat KUHAP yang mengintrodusir pendirian rubasan, sampai sekarang rubasan hanya mampu didirikan di Jakarta saja. Hal ini ingin ditegaskan bahwa penciptaan lembaga tersebut membutuhkan biaya luar biasa. 
Hakim Pemeriksa Pendahuluan (sebagaimana halnya Hakim Komisaris) dalam RUU HAP memiliki wewenang lebih luas dan lebih lengkap dibandingkan dengan lembaga praperadilan dalam KUHAP. Hakim Pemeriksa Pendahuluan adalah pejabat yang diberi wewenang menilai jalannya penyidikan dan penuntutan, dan wewenang lain yang ditentukan dalam KUHAP. Dalam Penjelasan RUU HAP, Hakim Pemeriksa Pendahuluan akan menggantikan lembaga praperadilan yang selama ini belum berjalan sebagaimana mestinya.

Kehadiran Hakim Pemeriksa Pendahuluan dalam RUU HAP melahirkan polemik dari berbagai kalangan khususnya para pakar hukum pidana. Ada pendapat yang menyatakan bahwa keberadaan Hakim Pemeriksa Pendahuluan merupakan hal sangat baik dan ideal dalam upaya penegakan hukum, namun dalam implementasinya tidak mungkin dilaksanakan saat ini. Hal ini karena sedikitnya jumlah hakim, termasuk masih sedikitnya jumlah permohonan praperadilan oleh masyarakat, juga dibutuhkan komitmen yang sungguhsungguh dari pemerintah, karena pembentukan Hakim Pemeriksa Pendahuluan tersebut akan memerlukan tenaga dan biaya yang sangat tinggi.

Pendapat lain menyatakan bahwa jumlah hakim pengadilan umum yang ada saat ini saja masih dinilai kurang. Selain itu, Hakim Pemeriksa Pendahuluan hanya memeriksa dan mengesahkan penyidik polisi melakukan penangkapan, penggeledahan dan penahanan, tanpa menangani perkara karena posisinya memang di luar pengadilan umum.

Mantan Ketua Mahkamah Agung Harifin Andi Tumpa berpendapat bahwa diperlukan tiga rambu dalam membentuk Hakim Pemeriksa Pendahuluan dalam RUU HAP, yaitu: Pertama, kesiapan lembaga peradilan khususnya Pengadilan Negeri yang melaksanakan ketentuan itu. Kedua, persyaratan menjadi Hakim Pemeriksa Pendahuluan. Ketiga, harus dihindari adanya benturan antara penegak hukum itu sendiri yang dapat mengakibatkan saling menyalahkan antara satu dengan yang lainnya. Menurut Romli Atmasasmita, bahwa kehadiran Hakim Pemeriksa Pendahuluan dalam sistem peradilan pidana Indonesia akan 
memicu meluasnya konflik antar lembaga kekuasaan kehakiman yang tidak kunjung selesai.

\section{Penutup}

\section{A. Kesimpulan}

1. Lembaga praperadilan dalam sistem peradilan pidana memiliki fungsi sebagai lembaga pengawas oleh Hakim terhadap tindakan-tindakan yang dilakukan oleh Kepolisian maupun Kejaksaan pada tahap pemeriksaan pendahuluan. Adapun tujuan pengawasan yang dilakukan oleh lembaga praperadilan adalah untuk memberikan perlindungan terhadap hak-hak asasi manusia terutama tersangka dan terdakwa. Akan tetapi dalam kenyataannya lembaga praperadilan ternyata belum efektif karena ditemukan banyak kelemahan dan kekurangan serta dalam prakteknya tidak sesuai dengan ketentuan dalam KUHAP. Kelemahan dan kekurangan tersebut antara lain yaitu masih terbatasnya kewenangan praperadilan terkait pengawasan terhadap upaya paksa yang hanya meliputi penangkapan dan penahanan. Hakim praperadilan bersifat menunggu, sehingga tidak ada pemeriksaan jika tidak ada pihak yang mengajukan permohonan. Dalam praktek hakim hanya memeriksa mengenai syarat formil dari suatu upaya paksa tanpa memperhatikan syarat materiil. Selain itu perbedaan dasar pertimbangan hakim dalam menjatuhkan putusan dan juga dibatasinya waktu yang singkat dalam 18 pemeriksaan perkara sesuai dengan pasal 82 ayat (1) huruf c KUHAP sehingga perkara gugur dengan sendirinya. Tidak hanya itu, terkait juga dengan pasal 80 KUHAP yaitu mengenai interpretasi pihak ketiga yang berkepentingan dalam mengajukan permohonan praperadilan.

2. Praperadilan merupakan lembaga baru dalam KUHAP, bersamaan dengan inovasi-inovasi yang lain seperti limitasi atas proses penangkapan atau penahanan, yang membuat KUHAP disebut juga karya agung bangsa Indonesia. Hal-hal tersebut dipertegas bahwa 
klausula KUHAP mengatur dalam penerapan upaya-upaya paksa (dwang midelen) sebagaimana dimungkinkan dalam proses peradilan pidana seperti penangkapan dan penahanan, tidak merendahkan harkatmartabat manusia. Berkenaan dengan hal tersebut, diperkenankanlah lembaga baru untuk melakukan pengawasan antar lembaga dalam proses peradilan pidana terpadu, yaitu lembaga praperadilan.

\section{B. Saran}

Berdasarkan pada uraian mengenai lembaga praperadilan dan mengingat pentingnya kedudukan hukum lembaga praperadilan dalam sistem peradilan pidana di Indonesia maka disarankan agar kewenangan kelembagaan ini diperluas dengan catatan perluasan ini tetap menjamin kemandirian lembaga penyidik dan penuntut umum dengan maksud untuk penguatan pengawasan internal dan eksternal. Dengan kalimat lain, perluasan tersebut sebaiknya dilegitimasi dengan regulasi terlebih dahulu, sehingga memberikan suatu kepastian hukum.

\section{Daftar Pustaka}

Alfiah, Ratna Nurul. Praperadilan dan Ruang Lingkupnya. Jakarta: Akademika Pressindo C.V., 1986.

Atmasasmita, Romli. Bunga Rampai Hukum Acara Pidana. Bandung: Binacipta (Anggota IKAPI), 1983.

Badan Pembinaan Hukum Nasional. Hakim Komisaris dalam Sistem Peradilan di Indonesia. Jakarta: 2011.

Hiariej, Eddy O.S. "Hal Ihwal Praperadilan". Makalah disampaikan dalam harian Kompas, Jakarta, 8 April 2015.

Sasangka, Hari. Penyidikan, Penahanan, Penuntutan, dan Praperadilan dalam Teori dan Praktek. Bandung: CV. Mandar Maju, 2007.

Pangaribuan, Luhut M.P. Lay Judges \& Hakim Ad Hoc, Suatu Studi Teoritis Mengenai Sistem Peradilan Pidana Indonesia. Jakarta: Papas Sinar Harapan, 2009. 